\title{
ANALISIS DEMOGRAFI PEMEGANG KARTU KREDIT MELALUI MARKETING COMMUNICATION PADA BNI CARD CENTER SURABAYA
}

\author{
Wenti Krisnawati \\ Fakultas Ekonomi dan Bisnis, Universitas Muhammadiyah Gresik, \\ Gresik, Indonesia, wentikrisnawati@umg.ac.id
}

\begin{abstract}
Background - During a period that was very vulnerable to competition in the banking industry, it encouraged the banking industry to quickly adjust ; to the development of the needs and desires and demands of the surrounding community regarding banking products. Current developments in the use of credit cards occur quickly because there are many conveniences obtained from the use of credit cards.

Diterima : 02 Januari 2020

Direview : 10 Januari 2020

Direvisi : 15 Januari 2020

Disetujui : 29 Januari 2020

Research Objectives - To find out and determine the demographics of credit card holders in BNI based on marketing communication strategies.

Design / methodology / approach- Research is focused on a qualitative approach with a case study methodology, the population in this study is BNI credit card holders, a sample of 21 BNI Credit card holders and using triangulation for data validity.

Results and Discussion - The results of the interview data for choosing a credit card holder to use a BNI credit card are to shop and meet the needs of self-actualization rather than basic needs, the results of the interview also show that the concept of integrated marketing communication is that the customer knows and and ultimately has a BNI credit card due to advertising in electronic and digital media.

Conclusion - Demographically the job as an entrepreneur / entrepreneur is a customer who has a lot of BNI credit cards and reasons to facilitate customer shopping activities.

Implication research - Based on the results of the research that has been made, this research contributes to the marketing communication strategy in the banking business environment and other industries by paying attention to each element of demographic segmentation.

Limitations research - For further research try to analyze more specifically about complaints on credit card payments because this research is very broad regarding marketing and demographic communication.
\end{abstract}

Keywords: Credit Card, Marketing Communication, Consumer Behavior

\begin{abstract}
ABSTRAK
Latar belakang - Pada masa yang sangat rentan dengan persaingan dalam industri perbankan mendorong industry perbankan untuk cepat menyesuaikan diri dengan adanya perkembangan kebutuhan dan keinginan serta permintaan masyarakat di sekitarnya mengenai produk perbankan. Perkembangan saat ini penggunaan kartu kredit terjadi dengan cepat karena ada banyak kemudahan yang diperoleh dari penggunaan kartu kredit.

Tujuan - Untuk mengetahui serta menentukan demografi pemegang kartu kredit pada BNI berdasarkan strategi komunikasi pemasaran.

Desain/ Metodologi/ Pendekatan - Penelitian difokuskan pada pendekatan kualitatif dengan metodologi studi kasus, Populasi dalam penelitian adalah pemegang kartu kredit BNI, sampel 21 orang pemegang kartu Kredit BNI serta memakai triangulasi untuk keabsahan data.

Hasil dan Pembahasan - Hasil data wawancara pemegang kartu kredit memilih untuk menggunakan kartu kredit BNI adalah untuk berbelanja dan mencukupi kebutuhan aktualisasi diri bukan kebutuhan pokok, hasil wawancara juga menunjukkan bahwa konsep komunikasi pemasaran terpadu yaitu
\end{abstract}


nasabah mengetahui dan dan akhirnya memiliki kartu kredit BNI dikarenakan adanya periklanan yang ada di media elektronik serta digital.

Kesimpulan - Secara demografi pekerjaan sebagai wiraswasta/pengusaha adalah nasabah yang banyak memiliki kartu kredit BNI dan alasan memudahkan aktifitas berbelanja nasabah.

Implikasi penelitian - Berdasarkan pada hasil penelitian yang telah dibuat maka penelitian ini berkontribusi terhadap strategi komunikasi pemasaran di lingkungan bisnis perbankan dan industri lainnya dengan memperhatikan masing-masing unsur segmentasi demografi.

Batasan penelitian - Untuk penelitian selanjutnya mencoba menganalisa lebih spesifik lagi yaitu mengenai keluhan pada pembayaran kartu kedit karena penelitian ini sangat luas mengenai komunikasi pemasaran dan demografi.

Keywords - Kartu Kredit, Komunikasi, Perilaku Konsumen

\section{PENDAHULUAN}

Penerapan untuk strategi pemasaran di dalam suatu perusahaan sangat wajar dan sering terjadi perubahan sejalan dengan perkembangan dan perubahan lingkungan industri yang ada. Sebenarnya perubahan tersebut mengharuskan perusahaan untuk terus menyesuaikan diri dengan perkembangan di lingkungan sekitarnya. Strategi diciptakan adalah untuk dapat memenangkan persaingan dengan menawarkan konsep yang jelas dari produk serta keunggulan khas yang ada di dalamnya.

Perusahaan jasa pada saat ini lebih banyak menekankan pada konsep pemasaran dengan melakukan pendekatan kepada konsumennya, perusahaan juga pada memperhatikan bahwa betapa sangat pentingnya kepuasan konsumen bagi kelangsungan hidup perusahaannya dalam jangka panjang. Perusahaan juga harus memperhatikan unsur kepuasan konsumen tersebut sebagai dasar untuk membangun loyalitas konsumen terhadap produk atau jasa yang diciptakannya/ perusahaan ciptakan (Infobank, Januari 2008).

Kartu kredit yaitu alat bayar dimana ini adalah untuk pengganti uang tunai yang biasa digunakan oleh para konsumen untuk ditukarkan kembali dengan barang dan jasa yang diinginkan di suatu tempat yang mana juga dapat menerima pembayaran dengan menggunakan kartu kredit (merchant).

Kartu Kredit sendiri adalah Alat Pembayaran yang biasanya Menggunakan Kartu dan dapat digunakan untuk melakukan sebuah pembayaran atas kewajiban pemakai yang timbul dari suatu kegiatan ekonomi sperti belanja, dan termasuk juga transaksi pembelanjaan dan/atau untuk melakukan penarikan atau transaksi tunai dimana kewajiban dan atas pembayaran pemegang kartu dipenuhi terlebih dahulu oleh penerbit, dan pemegang kartu yang berkewajiban melakukan pelunasan pembayaran tersebut pada waktu yang disepakati baik secara sekaligus ataupun secara angsuran. 
Kehidupan masyarakat pekotaan saat ini tidak terlepas dari gaya hidup yang serba ada. Gaya hidup masyarakat seiring berubah sesuai perkembangan zaman yang ada. Faktor terbesar yang mempengaruhi perkembangan masyarakat perkotaan untuk dapat bertahan hidup ialah meningkatnya kebutuhan individu yang tinggal didalam kota. Bagi sebagian masyarakat yang ada dikota kota-kota besar khususnya di kota surabaya, jakarta, pola konsumsi dan kebutuhan hidup akan kepraktisan, membuat jasa keuangan yang ada akan memberikan fasilitas serta pelayanan yang sesuai dengan kebutuhan masyarakat tersebut yakni kartu kredit.

Bersumber pada penelitian terdahulu, ditemukan sejumlah rujukan yang mengarah pada pentingnya sebuah komunikasi pemasaran kartu kredit BNI sehingga mampu meningkatkan jumlah pemegang kartu kredit dan nasabah mengerti mengenai manfaat kartu kredit BNI sehingga kepuasan nasabah menjadi lebih meningkat, dan pada gilirannya semakin meningkatkan loyalitas nasabah. Dengan meningkatnya loyalitas nasabah, diharapkan nasabah pemegang credit card akan dengan senang hati menceritakan pengalamannya selama menggunakan credit card tersebut baik kepada teman-teman, sahabat, maupun keluarganya dan akan mereferensikan mereka untuk juga menggunakannya, sehingga hal ini pada
E-ISSN : 2621-5055

gilirannya akan dapat meningkatkan jumlah pemegang kartu kredit BNI.

\section{TINJAUAN PUSTAKA}

\section{Konsep Pemasaran}

Pendapat para ahli terakhir mengenai pengertian segmentasi pasar yaitu menurut Kotler dan Gary (2001). Menurutnya, pengertian dari segmentasi pasar ialah pembagian sebuah pasar menjadi beberapa kelompok pembeli yang berbeda-beda. Segmentasi pasar mmiliki tujuan ialah untuk membagi pasar yang heterogen atau yang menjadi kelompok pasar yang homogen atau sejenis dan yang mana setiap kelompoknya dapat ditargetkan untuk memasarkan suatu produk sesuai dengan kebutuhan, keinginan, atau karakteristik setiap pembeli yang ada di pasar tersebut.

\section{Kategori Segmentasi Pasar}

\section{a. Demografis}

Segmentasi pasar berdasarkan peta demografis adalah dimana ketika pelaku pasar membagi pelanggan menjadi beberapa kelompok berdasarkan beberapa hal yaitu informasi demografis mereka, seperti: usia, jumlah pendapatan, jenis kelamin, termasuk tingkat pendidikan, status pernikahan, ras, jabatan atau kedudukan agama, dan banyak lagi. Tipe segmentasi ini adalah yang paling popular yang dipilih karena tipe ini yang paling mudah dan dapat diandalkan prosesnya. 


\section{b. Geografis}

Segmentasi pasar yang berdasarkan peta geografis adalah ketika pelaku pasar membuat pemisahan pelanggan berdasar tempat mereka berada atau tempat tinggal. Apabila skala bisnis yang telah kita sudah sampai di ranah internasional, atau segmentasinya yang bisa berupa antar beberapa benua atau beberpa negara.

\section{c. Behavioral atau Perilaku}

Metode ini membuat sebuah segmen berdasarkan perilaku atau sifat pelanggan, seperti bagaimana mereka mengunjungi sebuah situs web (halaman mana yang mereka kunjungi, tautan mana yang akan mereka klik, jam berapa mereka akan berbelanja, kapan terakhir kali mereka melakukan belanja, dan lain sebagainya).

\section{d. Psikografis}

Strategi ini menjelaskan tentang keyakinan, nilai, kepribadian, dan gaya hidup pelanggan. Semua sifat ini dapat pula mempengaruhi keputusan belanja mereka. Kelompok psikografis ini mungkin merupakan campuran dari beberapa jenis segmentasi lain, seperti usia pelanggan atau agama pelanggan (demografi) bahkan lokasi mereka (geografis).

\section{Komunikasi Pemasaran Terpadu}

a. Advertising (Periklanan)

Periklanan dapat diartikan sebagai sebuah penyampaian pesan melalui suatu media yang dapat dibayar sendiri oleh pemasang iklan. Banyak sekali peranan periklanan dalam pemasaran jasa adalah untuk membangun kesadaran akan jasa, dan menambah pengetahuan pelanggan terhadap suatu jasapositiojasa, serta utnuk membantu membujuk para pelanggan supaya membeli, dan untuk membedakan jasa serta penawaran jasa lain.

b. Personal Selling (Penjualan Perorangan) Penjualan perorangan adalah mengenai beberapa bentuk komunikasi antar individu dan dimana tenaga penjual menginformasikan, mendidik, serta melakukan persuasi kepada calon konsumen atau pembeli produk atau jasa dari perusahaan. Personal selling juga dapat diakatakan pula bersifat luwes, karena tenaga penjual harus dapat dan sanggup menyesuaikan diri secara langsung dengan kebutuhan serta perilaku masing-masing para calon pembeli. Ketika pelanggan senang interaksi ini akan menyebabkan kepuasan hingga mencapai loyalitas pelanggan (Jing Theng So dkk, 2015)

c. Sales Promotion (Promosi Penjualan)

Bentuk ini terdiri dari beberapa kegiatan pemasaran yang berusaha mencoba merangsang terjadinya pembelian konsumen dalam waktu yang singkat. Promosi penjualan juga mempunyai beberapa karakteristik yang menonjol, seperti perhatian, memberikan informasi yang sangat bernilai bagi konsumen. Memberikan kemudahan, bersifat 
membujuk, dan menggerakan konsumen untuk terlibat dalam suatu transaksi.

d. Public Relations(Hubungan Masyarakat) Tahap berikutnya Membangun hubungan dengan para baik dengan berbagai kalangan manapun untuk mendapatkan publisitas sesuai yang diinginkan.

\section{Pemasaran Langsung (Direct Marketing)}

Hubungan langsung dengan para konsumen individual dengan yang ditargetkan secara cermat untuk mendapatkan respon segera dan membangun hubungan pelanggan yang langgeng.

\section{Kerangka Berfikir}

Berikut dibawah ini pada gambar 1 merupakan kerangka atau alur berfikir yang digambarkan oleh peneliti.

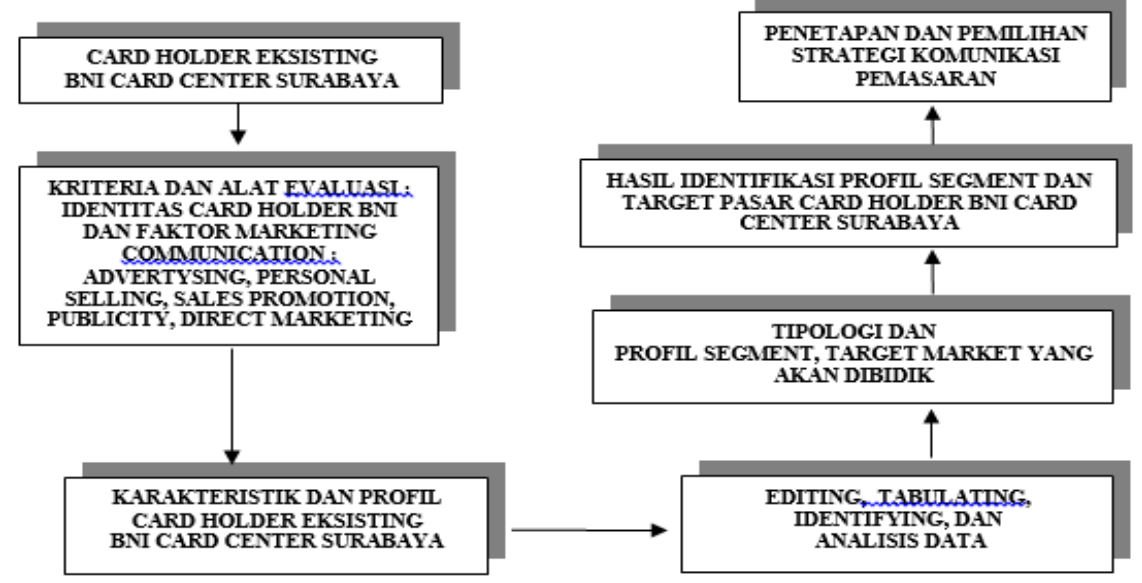

Gambar 1. Alur Berpikir

\section{METODOLOGI}

Penelitian ini lebih difokuskan pada pendekatan kualitatif dengan metodologi studi kasus (Yin, 2003). Studi Kasus juga merupakan strategi yang lebih sesuai jika pada pokok pertanyaan suatu penelitian ini berkaitan dengan how atau why. Bila peneliti hanya memiliki sedikit peluang untuk mengontrol peristiwa yang akan diselidiki serta bilamana fokus tujuan yang penelitiannya terletak pada fenomena kontemporer (masa kini) didalam konteks kehidupan nyata. Disamping itu, studi kasus lebih dikehendaki untuk melacak peristiwa-peristiwa kontemporer, bila peristiwa yang bersangkutan tak dapat dimanipulasi (Yin, 2003. Desain penelitian merupakan suatu rencana tindakan untuk berangkat dari sini kesana, 'dimana' 'disini' bisa diartikan juga sebagai rangkaian pertanyaan awal yang harus dijawab, dan merupakan suatu serangkaian jawaban mengenai pertanyaan-pertanyaan tersebut (Yin, 2003:20)

\section{Data Informan}


Informan merupakan sumber informasi atau orang yang dimanfaatkan untuk memberi informasi tentang permasalahan penelitian. Untuk memilih informan yang baik setidak-tidaknya ada beberapa kriteria yang harus diperhatikan. Kriteria informan yang baik adalah sebagai berikut:

1. Cukup lama dan intensif dengan informasi yang akan mereka berikan.

2. Masih terlibat penuh atau pernah terlibat penuh dengan kegiatan yang diinformasikan.

3. Mempunyai cukup banyak waktu untuk memberikan informasi.

4. Mereka tidak dikondisionalkan ataupun direkayasa dalam pemberian informasinya.

5. Mereka siap memberikan informasinya.

Berdasarkan uraian di atas, yang akan dijadikan informan pada penelitian ini yaitu:

1. 18 Informan (pengguna kartu kredit selama lebih dari 5 tahun)

2. Ibu Ika S (Asisten Pemasaran wilayah BNI Card Center Surabaya)

\section{Pengambilan data}

Data yang digunakan pada penelitian ini adalah data primer yang merupakan data yang diperoleh secara langsung dari perusahaan yang diteliti oleh peneliti. Data ini didapat dengan melakukan observasi langsung, rekaman arsip dan wawancara secara langsung secara mendalam dengan pihak-pihak terkait yang ada pada perusahaan. Menurut Bryman dan Bell
(2007), ada beberapa ciri lain dari penelitian kualitatif yaitu melihat permasalahan dari sudut pandang orang yang diteliti, memberikan deskripsi dan penekanan pada konteks permasalahan, dan menekankan pada proses.

\section{Analisis data}

Analisis data dalam penelitian ini dengan 3 tahapan, yakni tahap reduksi, display dan penarikan kesimpulan (verification). Sesuai dengan teori Analisis data dalam penelitian ini menggunakan teknik analisis data dalam situs yang dikembangkan oleh Miles Huberman. Data yang sudah terkumpul dibuat dalam matriks. Dalam matriks akan disajikan penggalan-penggalan data deskriptif sekitar peristiwa atau pengalaman tertentu yang menyekat data sebelum dan sesudahnya. Setelah data dimasukkan kedalam matriks selanjutnya di buat daftar cek (Miles Huberman, 2007: 139-140).

\section{Keabsahan data}

Penelitian ini menggunakan triangulasi sumber sebagai pengecekan keabsahan data. Triangulasi sumber dilakukan dengan cara membandingkannya dengan data yang diperoleh dari berbagai sumber lainnya tentang hal yang sama pada berbagai fase penelitian lapangan dalam waktu yang berlainan dan menggunakan metode berlainan. Informan pemilik kartu kredit BNI dan sumber (expert bidang perbankan) 


\section{HASIL DAN PEMBAHASAN}

Dalam penelitian ini, terdapat 18 Narasumber (NS) utama. Adapun kriteria NS yang digunakan dalam penelitian ini adalah para pemilik kartu Kredit BNI yang telah 5 tahun menjadi nasabah.

\section{Demografi Nasabah}

Hasil data wawancara mendalam menyoroti bahwa 18 narasumber pemegang kartu kredit berasal dari orang orang yang mempunyai latar belakang :

1. Pekerjaan sebagai wiraswasta dan pengusaha.

Pengusaha memiliki motivasi lebih tinggi dan kepercayaan diri dalam memiliki kartu kredit. Dan hal ini terjadi karena kebutuhan akan transaksi baik kecil maupun besar sering kali mengunakan kartu kredit. Seorang pengusaha yang sudah berpengalaman tentu akan memiliki tingkat memanajemen resiko dalam menjalankan usahanya dan transkasi. untuk transaksi kecil seperti berbelanja di toko minimal 2.000.000 mereka menggunakan kartu Kredit karena dianggap mudah

2. Penghasilan/ pendapatan diatas 10.000 .0000

Seperti telah diketahui bersama secara umum pengusaha adalah diatas rata rata karyawan UMR. Dengan keadaan inilah yang membuat mereka mampu untuk memiliki kartu kredit dan menggunakan sebagai transaksi mudah selain debit

3. Mempunyai hobi atau kesenangan yaitu menghabiskan waktu dengan travelling serta menggunakan kartu kredit untuk berbelanja dan mencukupi kebutuhan aktualisasi diri bukan kebutuhan pokok. Informan sangat percaya diri dan jelas mengatakan untuk aktualisasi diri seperti liburan dan belanja adalah hal yang paling sering dilakukan untuk bertransaksi.

\section{Komunikasi pemasaran}

Temuan lebih lanjut dari hasil wawancara juga menunjukkan bahwa konsep komunikasi pemasaran terpadu yaitu :

1. Nasabah tertarik memiliki kartu kredit BNI adalah dikarenakan adanya personal selling yang kuat misalnya: open table seperti halnya bank tersebut membuka stand di mall dan dengan di sertai SPG (Sales Prmotion Girl) dn SPB (Sales Promotion Boy) yang memiliki pengetahuan produk yang sangat baik. Kemampuan para tenaga sales yang dikerahkan ke lapangan baik di mall atau undangan perusahaan sangat menarik mereka para infroman untuk memiliki kartu kredit BNI. Dalam penelitian ini terdapat hasil untuk melakukan strategi komunikasi pemasaran yang bisa dilakukan dan dipertahankan adalah terkait dengan personal selling yang sangat membuat 
orang tertarik untuk memiliki kartu kredit BNI. Personal selling yang sering dilakukan oleh BNI card center surabaya cukup membuat orang tertarik untuk mmeilki kartu kredit tersebut. Walau kegiatan pemasaran sebuah produk dilakukan dengan mengunakan beberapa macam komunikasi atau kombinasi dari bentuk-bentuk komunikasi pemasaran, personal seliing memiliki sifat keunikan yaitu adanya tatap muka langsung dengan konsumen. Inilah peran penting dari personal selling yang tidak tergantikan oleh bentuk komunikasi pemasaran lainnya dan inilah yang dirasakan oleh para informan, mereka merasa nyaman dengan pertemuan atau tatap muka dan bertanya mengenai produk. Dalam kajian pemasaran, seperti dengan apa yang dikemukakan oleh Kotler dan Keller (2015) bauran komunikasi pemasaran (marketing communication mix) terdiri dari 8 (delapan) model komunikasi utama, yaitu : iklan, promosi penjualan, acara dan pengalaman, hubungan masyarakat dan publisitas, pemasaran langsung, interaktif, pemasaran dari mulut ke mulut dan penjualan personal. Penjualan personal merupakan bentuk komunikasi pemasaran yang tertua dengan benar-benar mengedepankan kunjungan penjualan lapangan. Menurut Kotler \& Keller (2015) pada saat ini sebagian besar perusahaan industri sangat bergantung pada tenaga penjualan professional untuk menemukan calon pelanggan, lalu mengembangkan menjadi pelanggan, dan menumbuhkan bisnis, atau mereka mempekerjakan perwakilan produsen dan agen untuk melaksanakan tugas penjualan langsung. Untuk mendukung kegiatan komunikasi pemasaran ini, perusahaan perlu menempatkan para tenaga penjualan secara strategis sehingga mereka bisa mengunjungi pelanggan yang tepat pada saat yang tepat pula dengan cara yang tepat. Saat ini wiraniaga bertindak sebagai "manajer pelanggan" mengatur hubungan yang produktif antara orangorang dalam organisasi pembelian dan penjualan (Kotler \& Keller, 2015). Begitu pula dengan informan penelitian ini sangat tertarik pada komunikasi pemasaran pesonal selling BNI Card Center.

2. Periklanan, ketika melihat iklan baik media elektronik dan digital para infroman merasa ada edukasi untuk produk BNI satu ini. Mulai dari cara penyampaian model iklan, dn manfaat yang di sajikan akan produk pada iklan tersebut.selain itu kemudahan belanja dan transaksi wisata 


\section{KESIMPULAN}

Dari hasil analisis dan pembahasan pada penelitian ini dapat dibuat kesimpulan yaitu 18 informan adalah para pekerja wiraswasta atau pengusaha, mmeiliki kartu kredit adalah hal untuk memudahkan mereka dalam bertransaksi aktualisasi diri seperti travelling dan 18 infoman ini juga mengatakan bahwa personal selling sangat membuat mereka yaitu para informan tertarik untuk memiliki karti kredit karena interaksi dengan penyedia jasa sangat baik dan lebih jelas untuk berinteraksi.

\section{IMPLIKASI PENELITIAN}

Berdasarkan pada hasil penelitian yang telah dibuat maka penelitian ini berkontribusi terhadap strategi komunikasi pemasaran di lingkungan bisnis perbankan dan industri lain dengan memperhatikan

\section{E-ISSN : 2621-5055}

masing-masing unsur segmentasi demografi. Setiap perusahaan yang memiliki tujuan komersil akan memerlukan komunikasi pemasaran untuk menyampaiakn produk kepada konsumen, dalam penelitian ini komunikasi pemasaran pesonal selling sangat tepat dilakukan pada bidang perbankan dan bidang sejenisnya seperti perusahaan asuransi. Karena personal selling lebih mampu berinteraksi dengan konsumen secara langsung.

\section{BATASAN PENELITIAN}

Pada penelitian ini variabel terlau luas yaitu demografi dan komunikasi pemasaran, untuk penelitian selanjutnya di sarankan lebih fokus pada hal seperti keluhan konsumen pada kartu kredit bank BNI 46.

\section{DAFTAR PUSTAKA}

Amstrong, Gery dan Philip Kotler. 2001. Prinsip-Prinsip Pemasaran. Jilid 1. Edisi Kedelapan. Jakarta: Erlangga.

Bryman, Alan and Emma Bell. 2007. Business Research Methods. New York: Oxford University Press

https://infobankstore.com/magazine/detail/2008/211/infobank-edisi-april-2008

https: / /www.bni.co.id/2019

Jing Theng So, Tracey Danaher, Samir Gupta, (2015)," What do customer get and give in return for loyalty program membership?, Australia, Monash University.

Kotler, Philip dan Kevin Lane Keller, 2015. Marketing Management, fifhteen edition, Jakarta, Erlangga

Miles, Matthew B. and A. Michael Huberman, 2007, Qualitative Data Analysis (terjemahan), Jakarta : UI Press.

Yin, Robert K, M.Djauzi Mudjakir (Penerjemah), 2003, Studi Kasus desain dan metode, Jakarta, PT. Raja Grafindo Persada. 